\title{
Factors Affecting Element Concentrations in Eggshells of Three Sympatrically Nesting Waterbirds in Northern Poland
}

\author{
Ignacy Kitowski ${ }^{1}$. Dariusz Jakubas ${ }^{2} \cdot$ Piotr Indykiewicz $^{3} \cdot$ Dariusz Wiącek $^{4}$
}

Received: 29 April 2017 / Accepted: 13 November 2017 / Published online: 23 November 2017

(C) The Author(s) 2017. This article is an open access publication

\begin{abstract}
Avian eggshells are convenient samples in biomonitoring studies, because they are easily accessible, especially from colonially or semicolonially breeding birds. In the present study, concentrations of 17 elements, including heavy metals and essential elements in post-hatch eggshells, were compared among three species of waterbirds of differing strategies for gaining reserves for egg production and diet: mallard, Anas platyrhynchos (ML, a capital breeder, mainly herbivorous), common tern, Sterna hirundo (CT, an income breeder, piscivorous) and black-headed gull, Chroicocephalus ridibundus (BHG, mixed strategy, omnivorous) and breeding sympatrically in three sites in North Poland. Analyses revealed that Fe, Zn, and $\mathrm{Cu}$ levels differed the most in the studied species, which may be explained by various contributions of fish, aquatic plants, and soil invertebrates in their diets. Generally, the studied species' eggshells accumulated amounts of elements comparable to those reported for other waterbirds without putting the growth and development of the embryo at risk. The only exception was very high levels of $\mathrm{Cr}$ in ML and CT, which may be explained by their foraging on aquatic organisms in waterbodies polluted by this element. Intersite differences in eggshell concentrations of $\mathrm{Ni}, \mathrm{Sr}, \mathrm{Hg}$ and $\mathrm{Cr}$ in $\mathrm{CT}$ (an income breeder) may be explained by the influence of local pollution sources (small factories, polluted river).
\end{abstract}

Avian eggshells are commonly used in studies focusing on bioindication and environmental monitoring (Lam et al. 2005; Ayas et al. 2008; Kim and Oh 2014; Khademi et al. 2015; Simonetti et al. 2015). Post-hatch eggshells are useful samples in biomonitoring studies, because they are easily accessible, especially from colonially or semicolonially breeding birds (Fu et al. 2014). Eggs are formed during a restricted period by adult females, which reduces the sources

Electronic supplementary material The online version of this article (https://doi.org/10.1007/s00244-017-0481-y) contains supplementary material, which is available to authorized users.

Piotr Indykiewicz

inpio@poczta.onet.pl

1 State School of Higher Education in Chełm, Pocztowa 54, 22-100 Chełm, Poland

2 Department of Vertebrate Ecology and Zoology, Faculty of Biology, University of Gdańsk, Wita Stwosza 59, 80-308 Gdańsk, Poland

3 Department of Biology and Animal Environment, University of Sciences and Technology, Kordeckiego 20, 85-225 Bydgoszcz, Poland

4 Institute of Agrophysics, Polish Academy of Sciences, Doświadczalna 4, 20-290 Lublin, Poland of variability (Sánchez-Virosta et al. 2015). During egg formation, females remove some contaminants from their bodies by sequestering them in the eggshells (Burger and Gochfeld 1996; Migula et al. 2000; Orłowski et al. 2014; Luo et al. 2016). However, the relationships among the various elements in the shells and contents vary between embryonated and non-embryonated eggs (Orłowski et al. 2016). The greater number of significant correlations has been found for embryonated eggs, which may be explained by the mobilization of elements (primarily accompanying intensive $\mathrm{Ca}$ resorption) from the shells to the egg contents (Orłowski et al. 2017). The eggshell serves as the major source of both $\mathrm{Ca}$ and $\mathrm{Mg}$ for the developing embryo (Packard and Packard 1991). Thus, ignoring the shell as a source of elements or in the element budget of the embryo undoubtedly prevents proper conclusions about the flux and bioaccumulation of contaminants in avian embryos (Orłowski et al. 2016).

Signals from eggshells reflect a short period of time (prelaying) and various spatial scales depending on the strategy for gaining nutrients for the eggs' production: capital breeders store nutrients before breeding, while income breeders obtain nutrients daily during the prelaying period (Stephens et al. 2009). Thus, the income breeders' levels of trace elements in eggs reflect contamination in the local breeding 
grounds, but in capital breeders, trace elements reflect contamination in wintering areas or stopover sites during spring migration.

This study focused on the concentrations of heavy metals and other elements in post-hatch eggshells of three sympatrically nesting waterbirds: black-headed gull, Chroicocephalus ridibundus (BHG), common tern, Sterna hirundo (CT), and mallard Anas platyrhynchos (ML), which differ in their strategies for gaining reserves for egg production and diet composition.

Mallard Anas platyrhynchos is an omnivorous duck. It is mainly herbivorous and granivorous, but it supplements its diet with locally available food, including aquatic invertebrates, fish, and amphibians, and in urban areas food waste of anthropogenic origin, such as bread (Cramp and Simmons 1977; Green and Selva 2000; Soons et al. 2016). Regarding its egg-formation strategy, ML is classified as a capital breeder (Boos et al. 2002; Butler and McGraw 2013).

The common tern, Sterna hirundo, is an opportunistic predator that changes prey as well as foraging behavior depending on local conditions (Bukacinski and Bukacinska 2015). It preys on fish and aquatic invertebrates, mainly crustaceans and insects (Becker and Ludwigs 2011; Bukacinski and Bukacinska 2015). Among the studied avian species, fish is the CT's most important diet component (Grajewska et al. 2015; Bukacinski and Bukacinska 2015; Indykiewicz $\mathrm{P}$, personal communication). Regarding its egg-formation strategy, CT is classified as an income breeder (Bond and Diamond 2010), obtaining nutrients on the breeding grounds during the prelaying period.

The black-headed gull, Chroicocephalus ridibundus, is an omnivorous gull with a diet consisting of invertebrates, especially earthworms, plants, and fish, and in urban areas, anthropogenic food waste (Vernon 1972; Cuendet 1983; Kitowski et al. 2017; Indykiewicz P., unpublished data). Regarding egg-formation, BHG adopts a mixed strategy to gain nutrients for egg production. Some nutrients are endogenous reserves acquired before breeding, whereas others are acquired near the breeding colony (Klaassen et al. 2004; Stephens et al. 2009).

The purpose of this study was to compare concentrations of heavy metals and other elements in post-hatch eggshells between species and sites. Considering the interspecies differences in diet composition and strategies for gaining nutrients for egg formation (Boos et al. 2002; Bond and Diamond 2010; Butler and McGraw 2013), interspecies differences in accumulating elements in eggshells were expected. Contamination of CT, ML, and BHG eggshells should indicate contamination in areas close to the breeding site, the last stopover site, or a mix of both areas, respectively. Given the common phenomenon of unintentionally swallowing lead shot pellets (mistaken for grit) by ML (Pain 1990; Szymczyk and Zalewski 2003; Mateo 2009), higher Pb concentrations are expected in the eggshells of this species compared with BHG and CT. Considering the high prevalence of fish in the diet of CT, higher concentrations of $\mathrm{Cu}$ and $\mathrm{Zn}$ may be expected compared to the more herbivorous ML. Considering the intersite differences in land cover, high levels of $\mathrm{Cu}$ and $\mathrm{Zn}$ in areas with high contributions from water bodies may be expected. Fish serves as the important source of those elements for piscivorous vertebrates (Radwan et al. 1990; Łuczyńska et al. 2009). Given that a diet rich in fish favors $\mathrm{Hg}$ accumulation in eggs, including the eggshells (Monteiro and Furness 1995; Grajewska et al. 2015; Ackerman et al. 2016), piscivorous CT and partly piscivorous BHG are predicted to have higher Hg levels in their eggshells. Given the intersite differences in habitat composition among the studied breeding sites (Table ES1), intersite differences in the element concentration in eggshells of the $\mathrm{CT}$, the only species gaining reserves for egg production locally, may be expected. Moreover, high $\mathrm{Cu}$ concentrations (due to high concentrations in aquatic prey) in eggshells in sites with extensive water bodies (Skoki Duże) and a high proportion of elements originating from fertilizers (e.g., Cd) in sites with extensive farmlands (Pakość) may be expected.

\section{Materials and Methods}

\section{Study Area}

Post-hatch eggshells were collected in spring 2015 in three sites in North (N) Poland, at Skoki Duże, Pakość, and Koronowo, where all studied species nest sympatrically (Table 1).

Most of the studied sites are located in areas with a prevalence of agricultural land (Fig. 1; Table ES1). Such a land structure was most marked at Pakość, where agricultural land constituted $85.8 \%$ of the area within $10 \mathrm{~km}$ (Fig. 1; Table ES1). Negligible aquatic habitats covered the $10-\mathrm{km}$ zones around the sites (Table ES1), except for Skoki Duże, where the Włocławek Reservoir (an artificial water body established after building the dam on the Vistula River) constituted $11.2 \%$ of the surrounding $10-\mathrm{km}$ zone.

Throughout the breeding season BHG feed mostly around the water bodies where their colonies are located, except at Pakość, where they feed mostly in arable fields. At Skoki Duże, the gulls forage in the Vistula River valley. Rubbish dumps are located within approximately $2 \mathrm{~km}$ of each colony that we monitored, except for the Skoki Duże colony. These dumps serve as an additional source of food for BHG (Indykiewicz P., unpublished data). ML and CT generally forage in the water bodies where they breed. CT sometimes forage in other nearby aquatic habitats (e.g., in the Vistula 


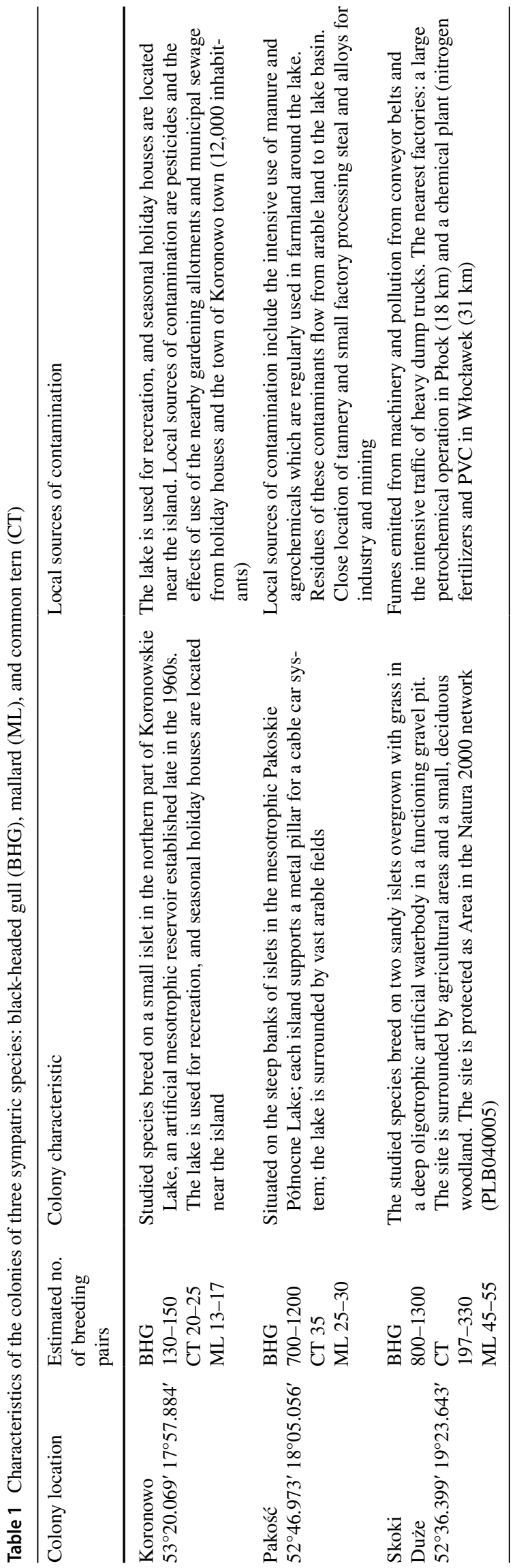

River at Skoki Duże). ML also forage in farmlands near the breeding site.

\section{Field Methods}

The black-headed gull laid eggs between the first week of April and first week of May, ML between the first half of April and the first half of June, and CT from the beginning to the end of May. BHG and CT nests were monitored every 2-3 days, ML every 3-4 days, and the post-hatched eggshells were collected. Eggshells were searched for within 3-4 $\mathrm{m}$ of the nest as soon as the chicks hatched. The collected eggshells were preliminarily cleaned of larger dirt, such as soil and feces, and then were placed in airtight containers and delivered to the laboratory. In total, 35 posthatch BHG eggshells were collected (12 at Skoki Duże, 12 at Pakość, and 11 at Koronowo), 34 ML (11 at Skoki Duże, 11 at Pakość, and 12 at Koronowo), and 36 CT (12 at Skoki Duże, 12 at Pakość, and 12 at Koronowo).

\section{Analytical Procedure}

Upon delivery to the laboratory the inner membrane of the eggshells was removed. Eggshells were washed with deionized water, rinsed with acetone, and ground in a ceramic mortar before measurements. All glassware and utensils was soaked in an acid bath $\left(5 \mathrm{M} \mathrm{HNO}_{3}\right)$ for $24 \mathrm{~h}$, rinsed with demineralized water, and dried under a laminar flow hood before use to minimize the risk of metal contamination. Samples $(500 \pm 1 \mathrm{mg})$ were mixed with $10 \mathrm{~mL}$ of concentrated $\mathrm{HNO}_{3}$ (Sigma Aldrich, Chempur, Poland) and wet ashed. Mineralization was carried out in a Microwave Digestion System with optical, temperature, and pressure monitoring of each sample during acid digestion (Berghof Speedwave, Eningen, Germany) in Teflon vials (type DAP 100). For mineralization details, see electronic supplementary material (ES2). The clear elemental solution obtained after mineralization was cooled to room temperature, transferred to $50-\mathrm{mL}$ flasks, and filled with demineralized water (ELGA Pure Lab Classic) to the indicated level. An iCAP Series 6500 inductively coupled plasma optical emission spectrometer (Thermo Scientific, USA) equipped with a charge injection device (CID) was used for element detection (iCAP 2010). The spectrometer was controlled with PCbased iTEVA software (see instrumental parameters in ES2).

Considering the mineralization method (dilution of $500 \mathrm{mg}$ of sample in $10 \mathrm{~mL}$ of $\mathrm{HNO}_{3}$ with a density of $1.51 \mathrm{~g} \mathrm{~cm}^{-3}$ ), the limit of $\mathrm{Hg}$ detection was estimated to $0.058 \mu \mathrm{g} \mathrm{L}^{-1}\left(3.72 \times 10^{-5} \mathrm{mg} \mathrm{kg}^{-1}\right)$.

Samples were run in batches (colonies) and each colony included a blank (control) sample. A certified reference material, TraceCERT - Periodic table mix 1 for ICP (Fluka 


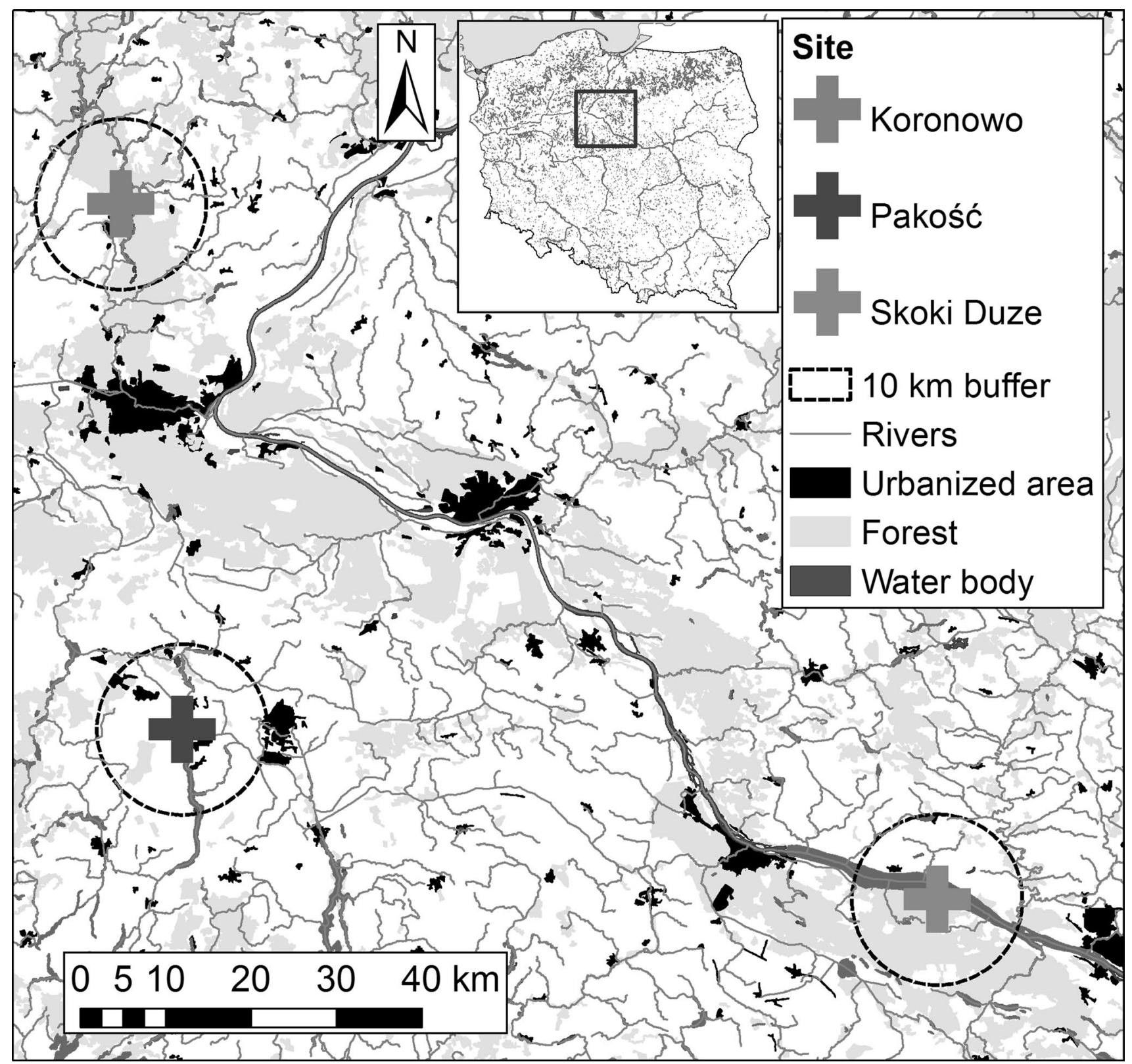

Fig. 1 Study area with the location of all studied sites (crosses) with 10-km buffers (dashed line), selected land cover types [according to the Corine Land Cover (CLC2006) model (http://www.eea.europa.

Analytical, Sigma Aldrich), was used to control the accuracy of the method under existing working conditions. Validation of the analytical method is described in ES2. All concentrations obtained in this study are given in $\mathrm{mg} \mathrm{kg}^{-1}$ dry weight (dw).

\section{Statistical Analyses}

To investigate variations in the qualitative and quantitative composition of trace elements in post-hatch eggshells, we used principal component analysis (PCA). This technique eu/, EEA Copenhagen, 2012)], and the nearest factories (pollution emission sources)

was applied to reduce the number of variables to a few new factors representing groups of elements with significantly correlated concentrations.

To compare the qualitative and quantitative compositions of all trace elements in eggshells among the studied species and sites, we applied following multivariate methods:

(1) Multivariate (for all elements together) PERMANOVA (nonparametric MANOVA based on the Bray-Curtis measure; Anderson 2001) with fixed factors (age and sex) and their interaction as explanatory variables; when the interaction effect was significant, intersite 
differences were compared exclusively for the income breeder, CT; (2) The similarity percentage breakdown (SIMPER) procedure to assess the average percentage contribution of individual factors to the dissimilarity between objects in a Bray-Curtis dissimilarity matrix (Clarke 1993); (3) Univariate analysis (for particular elements) using oneway PERMANOVA (nonparametric MANOVA based on the Bray-Curtis measure; Anderson 2001) with fixed factors (colony and sex) and their interaction as explanatory variables.

We assessed whether the data sufficiently met the assumptions of the linear model using Q-Q plots (quantile expected in normal distribution vs quantile observed plot for residuals). As the distribution of the obtained data was not normal, a $\log (x+1)$ transformation was used resulting in residuals with a normal distribution. Statistical analyses were conducted using STATISTICA 12.0 (StatSoft, Inc. 2014) and PAST 3.0 (Hammer et al. 2001).

\section{Results}

Variations in the qualitative and quantitative composition of trace elements in post-hatch eggshells

Principal component analysis (PCA) revealed that $82.3 \%$ of the total variance was explained by the three axes (Table 2). PC1 explained $53.6 \%$ of the total variance and was

Table 2 Values of principal component loadings for the studied elements in the eggshells of the examined species; moderately correlated values $(r>0.05)$ bolded

\begin{tabular}{lccr}
\hline Elements & \multicolumn{1}{c}{ PC 1 } & PC 2 & PC 3 \\
\hline $\mathrm{As}$ & 0.09 & 0.11 & -0.04 \\
$\mathrm{Ca}$ & 0.25 & 0.23 & -0.19 \\
$\mathrm{Cd}$ & 0.00 & 0.00 & 0.01 \\
$\mathrm{Cr}$ & -0.22 & -0.41 & 0.18 \\
$\mathrm{Cu}$ & -0.36 & -0.17 & 0.27 \\
$\mathrm{Fe}$ & $\mathbf{0 . 6 6}$ & -0.10 & $\mathbf{0 . 6 7}$ \\
$\mathrm{Hg}$ & -0.05 & -0.01 & 0.04 \\
$\mathrm{Mg}$ & 0.17 & -0.19 & -0.13 \\
$\mathrm{Mn}$ & -0.18 & 0.39 & $\mathbf{0 . 5 5}$ \\
$\mathrm{Mo}$ & 0.01 & 0.01 & -0.01 \\
$\mathrm{Ni}$ & -0.05 & 0.15 & 0.05 \\
$\mathrm{~Pb}$ & -0.06 & 0.06 & 0.07 \\
$\mathrm{Sc}$ & -0.03 & 0.03 & 0.03 \\
$\mathrm{Se}$ & 0.13 & -0.07 & -0.07 \\
$\mathrm{Sr}$ & -0.03 & $\mathbf{0 . 6 7}$ & -0.04 \\
$\mathrm{~V}$ & -0.18 & 0.21 & 0.12 \\
$\mathrm{Zn}$ & 0.43 & 0.05 & -0.23 \\
Eigen values & 0.36 & 0.10 & 0.09 \\
Total variance & 53.6 & 14.9 & 13.7 \\
explained $(\%)$ & & & \\
\hline
\end{tabular}

moderately positively correlated with Fe ( $r=0.66$; Table 2$)$. PC2 explained $14.9 \%$ of the total variance and was highly positively correlated with $\mathrm{Sr}(r=0.67)$. PC3 explained $13.7 \%$ of the total variance and was moderately positively correlated with Fe $(r=0.67)$ and $\mathrm{Mn}(r=0.55$; Table 2$)$. All of the studied species clustered in various positions in the PCA plot (Fig. 2). All of the BHG samples were the most clustered (Fig. 2).

\section{Intergroup Differences: All Elements Combined}

The concentrations of all combined studied elements were significantly affected by species (multivariate two-way PERMANOVA, similarity measure: Bray-Curtis, $F_{2,104}=146.1$, $p=0.0001)$, breeding site $\left(F_{2,104}=8.40, p=0.0001\right)$, and species $\times$ site interaction $\left(F_{2,104}=-2.55, p=0.0001\right)$. SIMPER analysis showed that $\mathrm{Fe}, \mathrm{Zn}$, and $\mathrm{Cu}$ contributed the most $(17,12$, and $10 \%$, respectively) to the pattern of overall dissimilarity observed in elemental concentrations (Table 3 ). Regarding the species $\times$ site interaction effect, one-way PERMANOVA indicated that elemental concentrations did not differ significantly among the BHG breeding sites $(p>0.11)$ or between the CT colonies at Pakość and Skoki Duże $(p=0.23)$. All of the other differences were significant (Table 4). SIMPER analysis showed that the following elements contributed the most $(>10 \%)$ to the pattern of interspecies dissimilarity: $\mathrm{Fe}, \mathrm{Zn}$, and $\mathrm{Cu}$ for $\mathrm{ML}-\mathrm{BHG}$; $\mathrm{Fe}, \mathrm{Cr}, \mathrm{Cu}, \mathrm{Ca}, \mathrm{Sr}$, and $\mathrm{Zn}$ for BHG-CT; and Fe, Mn, Sr, and Zn for ML-CT (Table 3).

\section{Intergroup Differences: Particular Elements}

Univariate PERMANOVA analyses performed separately for particular elements revealed that the levels of $\mathrm{As}, \mathrm{Cd}, \mathrm{Cu}$, $\mathrm{Fe}, \mathrm{Mo}$, and $\mathrm{Pb}$ in post-hatch eggshells were significantly affected only by species. Other studied factors were insignificant (Table ES3). The Mn and V levels in post-hatched eggshells were significantly affected by both species and site factors (Table ES3).

The As concentrations differed significantly among all species $(p=0.003)$ with the highest value in ML and the lowest in CT. Significantly higher levels of $\mathrm{Cd}$ were found in ML compared with CT $(p=0.0003)$ and BHG $(p=0.03$; Table ES4). All of the species differed significantly with respect to $\mathrm{Cu}(p=0.003)$, with the highest value in ML and the lowest in BHG. All of the species differed significantly $(p<0.01)$ in $\mathrm{Fe}$, with the highest value in BHG and the lowest in ML (Table ES4). Levels of Mo in all species differed significantly $(p<0.004)$, with the highest value in BHG and the lowest in CT (Table ES4). Concentrations of Pb differed significantly between ML and BHG $(p=0.0003)$ and ML and $\mathrm{CT}$, with the highest values in ML. The levels of $\mathrm{Pb}$ in CT and BHG were similar ( $p=1.0$; Table ES4). 


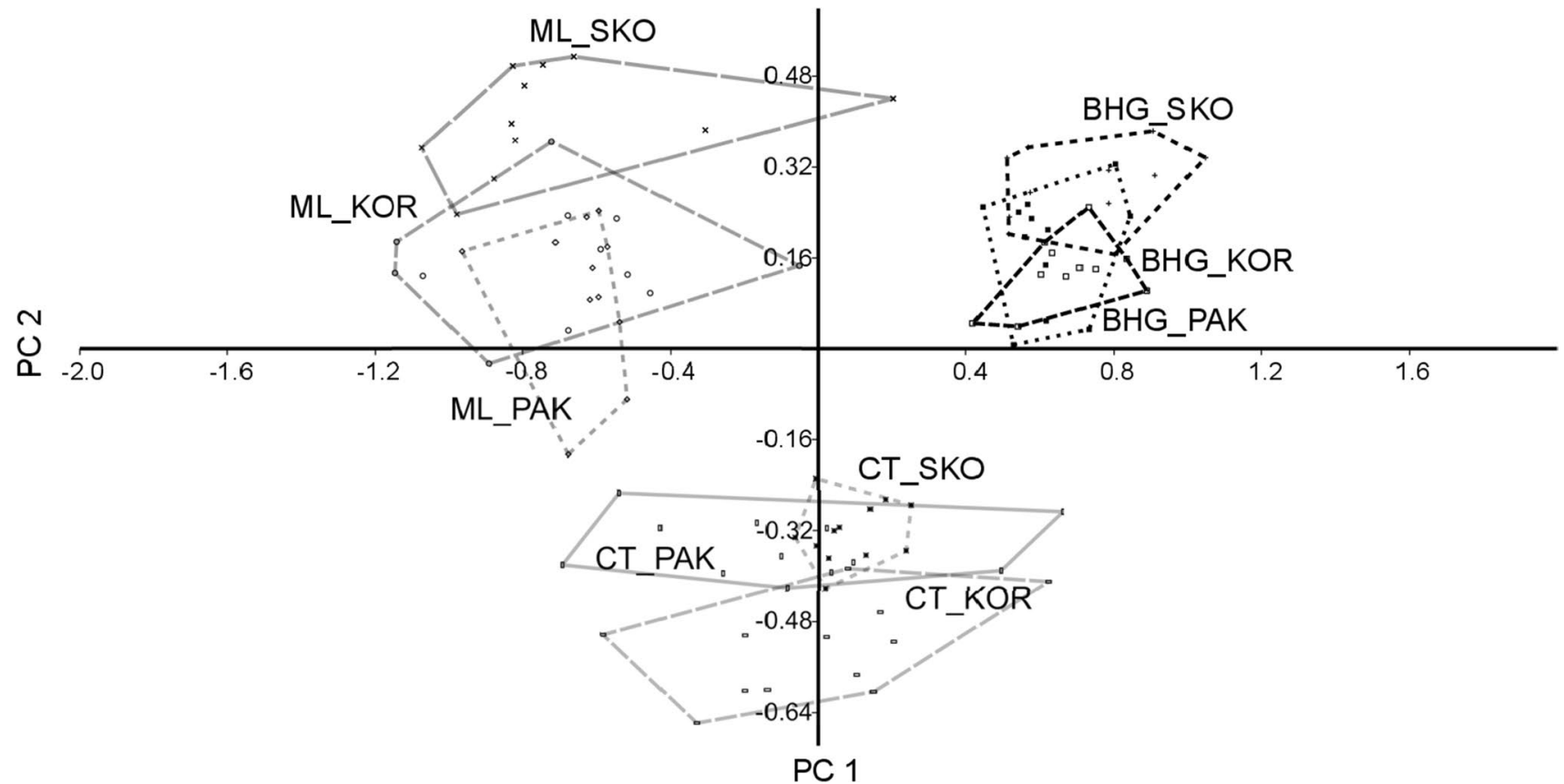

Fig. 2 PCA plot showing elemental concentrations in the eggshells of black-headed gulls (BHG), mallards (ML), and common tern (CT) breeding in Koronowo (KOR), Pakość (PAK), and Skoki Duże (SKO). Convex hulls contain all samples from one species and breeding site

Table 3 Sources of variability in the elemental concentrations $[\log (x+1)$ transformed] (average percentage dissimilarity) in the eggshells of three species of waterbirds from the studied sites according to a SIMPER analysis; only elements with a contribution $>10 \%$ are shown

\begin{tabular}{|c|c|c|}
\hline Element & Average dissimilarity & $\begin{array}{l}\text { Contribu- } \\
\text { tion }(\%)\end{array}$ \\
\hline \multicolumn{3}{|c|}{ Overall dissimilarity } \\
\hline $\mathrm{Fe}$ & 1.715 & 17.1 \\
\hline $\mathrm{Zn}$ & 1.224 & 12.2 \\
\hline $\mathrm{Cu}$ & 1.027 & 10.3 \\
\hline \multicolumn{3}{|c|}{ Interspecies-BHG-ML } \\
\hline $\mathrm{Fe}$ & 2.5 & 17.2 \\
\hline $\mathrm{Zn}$ & 2.0 & 13.6 \\
\hline $\mathrm{Cu}$ & 1.7 & 12.1 \\
\hline \multicolumn{3}{|c|}{ Interspecies-BHG-CT } \\
\hline $\mathrm{Fe}$ & 1.4 & 14.5 \\
\hline $\mathrm{Cr}$ & 1.4 & 13.8 \\
\hline $\mathrm{Cu}$ & 1.3 & 12.8 \\
\hline $\mathrm{Ca}$ & 1.3 & 12.7 \\
\hline $\mathrm{Sr}$ & 1.2 & 11.8 \\
\hline $\mathrm{Zn}$ & 1.1 & 11.5 \\
\hline \multicolumn{3}{|c|}{ Interspecies-ML-CT } \\
\hline $\mathrm{Fe}$ & 1.9 & 18.0 \\
\hline $\mathrm{Mn}$ & 1.5 & 14.4 \\
\hline $\mathrm{Sr}$ & 1.3 & 12.6 \\
\hline $\mathrm{Zn}$ & 1.1 & 10.5 \\
\hline
\end{tabular}

Species codes: $B H G$ black-headed gull, $M L$ mallard, $C T$ common tern
Mn levels differed significantly among the studied species $(p<0.004)$, with the highest value in ML and the lowest in CT (Table ES4). Regarding the site effect, Mn concentrations at Pakość tended to be lower than at Koronowo $(p=0.055$; Table ES5). Concentrations of V differed significantly among all studied species $(p=0.003)$, with the highest value in ML and the lowest in CT (Table ES4). The site effect was not significant (all $p>0.17$ ).

One-way PERMANOVA revealed that the concentrations of the remaining elements $(\mathrm{Ca}, \mathrm{Cr}, \mathrm{Hg}, \mathrm{Mg}, \mathrm{Ni}, \mathrm{Sc}, \mathrm{Se}, \mathrm{Sr}$, and $\mathrm{Zn}$ ) in post-hatch eggshells were significantly affected by interactions between species and site (species $\times$ site). It was accompanied by a significant effect of species $(\mathrm{Mg}, \mathrm{Zn})$ or both species and site $(\mathrm{Ca}, \mathrm{Cr}, \mathrm{Hg}, \mathrm{Ni}, \mathrm{Sc}, \mathrm{Se}, \mathrm{Sr}$; Table ES3).

To test the formulated hypotheses, further analyses of these elements were focused on interspecies differences and intersite differences exclusively for the income breeder, CT.

Regarding interspecies differences, $\mathrm{Mg}$ concentrations differed significantly between ML and BHG ( $p=0.0003$ ) and ML and CT ( $p=0.0003)$, with the lowest level in ML. Concentrations in CT and BHG were similar ( $p=1.0$; Table ES4). Levels of Ca in all species differed significantly among the species ( $p=0.0003$ ), with the highest value in BHG and the lowest in ML (Table ES4). Zn concentration differed significantly among all species $(p=0.0003)$, with the highest value in BHG and the lowest in ML (Table ES4). Cr concentrations differed significantly among all species $(p<0.002)$, with the highest value in CT and the lowest in BHG (Table 
Table 4 Intergroup differences (one-way PERMANOVA, $p$ values) in elemental concentration in eggshells of black-headed gulls (BHG), mallards (ML) and common tern (CT) breeding at Koronowo (KOR), Pakość (PAK), and Skoki Duże (SKO)

\begin{tabular}{llllllllll}
\hline Species/sites & BHG & BHG & BHG & ML & ML & ML & CT & CT & CT \\
& SKO & KOR & PAK & SKO & KOR & PAK & SKO & KOR & PAK \\
\hline BHG_SKO & & 0.212 & 0.295 & $\mathbf{0 . 0 0 4}$ & $\mathbf{0 . 0 0 4}$ & $\mathbf{0 . 0 0 4}$ & $\mathbf{0 . 0 0 4}$ & $\mathbf{0 . 0 0 4}$ & $\mathbf{0 . 0 0 4}$ \\
BHG_KOR & 0.212 & & 0.112 & $\mathbf{0 . 0 0 4}$ & $\mathbf{0 . 0 0 4}$ & $\mathbf{0 . 0 0 4}$ & $\mathbf{0 . 0 0 4}$ & $\mathbf{0 . 0 0 4}$ & $\mathbf{0 . 0 0 4}$ \\
BHG_PAK & 0.295 & 0.112 & & $\mathbf{0 . 0 0 4}$ & $\mathbf{0 . 0 0 4}$ & $\mathbf{0 . 0 0 4}$ & $\mathbf{0 . 0 0 4}$ & $\mathbf{0 . 0 0 4}$ & $\mathbf{0 . 0 0 4}$ \\
ML_SKO & $\mathbf{0 . 0 0 4}$ & $\mathbf{0 . 0 0 4}$ & $\mathbf{0 . 0 0 4}$ & & $\mathbf{0 . 0 0 4}$ & $\mathbf{0 . 0 0 4}$ & $\mathbf{0 . 0 0 4}$ & $\mathbf{0 . 0 0 4}$ & $\mathbf{0 . 0 0 4}$ \\
ML_KOR & $\mathbf{0 . 0 0 4}$ & $\mathbf{0 . 0 0 4}$ & $\mathbf{0 . 0 0 4}$ & $\mathbf{0 . 0 0 4}$ & & $\mathbf{0 . 0 0 4}$ & $\mathbf{0 . 0 0 4}$ & $\mathbf{0 . 0 0 4}$ & $\mathbf{0 . 0 0 4}$ \\
ML_PAK & $\mathbf{0 . 0 0 4}$ & $\mathbf{0 . 0 0 4}$ & $\mathbf{0 . 0 0 4}$ & $\mathbf{0 . 0 0 4}$ & $\mathbf{0 . 0 0 4}$ & & $\mathbf{0 . 0 0 4}$ & $\mathbf{0 . 0 0 4}$ & $\mathbf{0 . 0 0 4}$ \\
CT_SKO & $\mathbf{0 . 0 0 4}$ & $\mathbf{0 . 0 0 4}$ & $\mathbf{0 . 0 0 4}$ & $\mathbf{0 . 0 0 4}$ & $\mathbf{0 . 0 0 4}$ & $\mathbf{0 . 0 0 4}$ & & $\mathbf{0 . 0 0 4}$ & 0.227 \\
CT_KOR & $\mathbf{0 . 0 0 4}$ & $\mathbf{0 . 0 0 4}$ & $\mathbf{0 . 0 0 4}$ & $\mathbf{0 . 0 0 4}$ & $\mathbf{0 . 0 0 4}$ & $\mathbf{0 . 0 0 4}$ & $\mathbf{0 . 0 0 4}$ & & $\mathbf{0 . 0 3 6}$ \\
CT_PAK & $\mathbf{0 . 0 0 4}$ & $\mathbf{0 . 0 0 4}$ & $\mathbf{0 . 0 0 4}$ & $\mathbf{0 . 0 0 4}$ & $\mathbf{0 . 0 0 4}$ & $\mathbf{0 . 0 0 4}$ & 0.227 & $\mathbf{0 . 0 3 6}$ & \\
\hline
\end{tabular}

Significant $(p<0.05)$ values bolded
ES4). Hg levels differed significantly among all species studied $(p=0.0003)$, with the highest value in ML and undetectable values in BHG (Table ES4). Ni concentrations differed significantly among all species $(p=0.0003)$, with the highest value in ML and lowest in CT (Table ES3). Sc concentrations in $\mathrm{CT}$ were considerably higher than in BHG $(p=0.0003)$ and ML $(p=0.001$; Table ES4). Se concentration differed significantly among all species $(p=0.0003)$, with the highest value in BHG and the lowest in ML (Table ES3). Sr levels in CT were considerably lower than in BHG $(p=0.0003)$ and ML $(p=0.0003$; Table ES4).

\section{Intersite Differences in the Income Breeder, CT}

Univariate PERMANOVA revealed lack of significant interaction effect for $\mathrm{As}, \mathrm{Cd}, \mathrm{Cu}, \mathrm{Fe}, \mathrm{Mn}, \mathrm{Pb}$, and $\mathrm{V}$ (Table ES3). For elements with significant species $\times$ site interaction effect $(p>0.05)$, there were no significant intersite differences for $\mathrm{CT}$ in the concentrations of $\mathrm{Ca}(p>0.65), \mathrm{Mg}(p=1.0)$, $\mathrm{Sc}(p>0.12)$, or $\mathrm{Zn}(p=1.0)$. The $\mathrm{Cr}$ values at Koronowo were significantly lower than at Pakość ( $p=0.04$; Table ES5). The same pattern was found for $\mathrm{Hg}$, with significantly lower values in CT eggshells from Koronowo compared with Pakość ( $p=0.01$; Table ES5). Eggshell Ni concentrations at Koronowo were significantly lower than at Pakość $(p=0.004)$ and Skoki Duże ( $p=0.004$; Table ES5). The Se values at Skoki Duże were significantly higher compared to Pakość ( $p=0.004)$ and Koronowo $(p=0.007$; Table ES5). Significantly lower $\mathrm{Sr}$ concentrations in CT were found in Koronowo compared with Pakość $(p=0.003)$ and Skoki Duże ( $p=0.004$; Table ES5).

\section{Discussion}

To our knowledge, this is the first study to compare elemental concentrations in post-hatch eggshells collected in one area from three species of sympatrically breeding waterbirds adopting various strategies of obtaining nutrients for egg formation.

Interspecies differences in concentrations of selected essential elements (iron, zinc, copper, calcium, manganese)

Fe and $\mathrm{Zn}$ contributed considerably ( $>10 \%)$ to all pairs of interspecies dissimilarities (Table 3). Fish tissues are an important source of $\mathrm{Zn}$ and Fe (Radwan et al. 1990; Łuczyńska et al. 2009), which may explain the high values of these elements in partly piscivorous BHG and their low values in mainly herbivorous/granivorous ML (Table ES4). Conversely, one should expect the highest Fe and $\mathrm{Zn}$ values in piscivorous CT. However, CT is an opportunistic predator that may switch from fish to other prey (Becker and Ludwigs 2011; Bukacinski and Bukacinska 2015). Thus, we cannot exclude that the relatively late arrival of CT to the breeding colony before egg formation may supplement their piscivorous diet with invertebrates, which results in lower levels of those elements in eggshells than expected. $\mathrm{Zn}$ concentration was the highest in BHG, which frequently forage on earthworms (Cuendet 1983), known for their high absorption of this essential element [concentrations ( $\mathrm{mg} \mathrm{kg}^{-1} \mathrm{dw}$ ) for species occurring in Poland: Lumbricus terrestris-790-1066, Aporrectodea caliginosa-401-1530, and Eisenia fetida - 450-617 (Łaszczyca et al. 2004)]. Natural and mineral fertilizers serve as an important source of the total annual input of $\mathrm{Zn}$ into agricultural soils (Nicholson et al. 2003). Similar high $\mathrm{Zn}$ concentrations in eggshells of the same species have been reported for other parts of Poland (Table ES6, Table ES7).

$\mathrm{Cu}$ contributed considerably to the dissimilarity for the species pairs BHG-ML and BHG-CT (Table 3). Aquatic plants and fish serve as the most important sources of this 
element. High $\mathrm{Cu}$ accumulation in internal organs has been reported for piscivorous avian species (Nam et al. 2005; Horai et al. 2007; Skoric et al. 2012) and herbivorous anatids (Schummer et al. 2011; Komosa et al. 2012). The eggshell $\mathrm{Cu}$ concentration pattern (ML $>\mathrm{CT}>\mathrm{HG}$ ) probably reflects different contributions of those food types in the diets of the studied species, with a high contribution of aquatic plants in herbivorous/granivorous ML, a high contribution of fish in $\mathrm{CT}$, and the lowest contribution of aquatic food in BHG.

$\mathrm{Ca}$ - the most important element to affect eggshell structure-contributed considerably to the interspecies dissimilarity in elemental concentration in the eggshells for the species pair BHG-CT (Table 3), with the highest concentration in the former species (Table ES4). Those high values in BHG may have resulted from a high-diversity diet consisting of important Ca sources, such as fish (Łuczyńska et al. 2009; Lidwin-Kazmierkiewicz et al. 2009), plants (Schierup and Larsen 1981; Brix and Lyngby 1983; Obolewski et al. 2010), or invertebrates (earthworms and mollusks) (Wheeler 1992; Morgan and Morgan 1991, 1999; Jurkiewicz-Karnkowska 2005). The low concentrations of Ca in CT (Table ES4) may be attributed to less frequent grit ingestion and a less diverse diet consisting mainly of fish compared with BHG in studied colonies (Indykiewicz P, unpublished data).

Similar to $\mathrm{Zn}$, proper amounts of Mn have a positive impact on eggshell density, thickness, and the hatchability of eggs (Leach and Gross 1983; Swiatkiewicz and Koreleski 2008). The Mn concentration in the post-hatch eggshells of the studied ML (3.61 $\mathrm{mg} \mathrm{kg}^{-1}$ ) was the highest reported for waterbirds (Table ES6, Table ES7). As in the case of $\mathrm{Cu}$, the observed Mn accumulation sequence ML $>\mathrm{BHG}>\mathrm{CT}$ (Table ES4) reflects the contribution of aquatic plants in the birds' diet. This kind of food is rich in Mn (SameckaCymerman and Kempers 2000; Demirezen and Aksoy 2006; Parzych et al. 2016) as water plants are able to accumulate up to $500 \mathrm{mg} \mathrm{kg}^{-1}$ of $\mathrm{Mn}$ without negative effects (Allen 1989).

\section{Interspecies Differences in Concentrations of Selected Heavy Metals and Strontium}

Sr contributed considerably to inter-species dissimilarity in elemental concentrations in the eggshells for the species pairs BHG-CT and ML-CT (Table 3). The very low concentrations of this element observed in CT eggshells (Table ES4) may be attributed to less frequent grit (gastrolith) ingestion in this mainly piscivorous tern. Grit serves as an important source of Ca during egg formation (Bendell-Young and Bendell 1999; Gionfriddo and Best 1999; Sherfy et al. 2001). Sr is strongly associated with Ca metabolism; thus, higher Ca requirements for the female during egg production result in increased $\mathrm{Ca}$ absorption as well as increased absorption of $\mathrm{Sr}$ (Kottferova et al. 2001; Mora 2003).

In agreement with expectations, ML eggshells accumulated 32 times more $\mathrm{Pb}$ than the other studied species (Table ES4). However, all of those values were relatively low compared with those reported for other waterbird species (up to $88.5 \mathrm{mg} \mathrm{kg}^{-1} \mathrm{dw}$; Table ES6, Table ES7). Lead shot pellets are commonly swallowed as grit by mistake, which is the common source of $\mathrm{Pb}$ contamination in ducks, including MLs (Figuerola et al. 2005; Martinez-Haro et al. 2011). Fertilizer runoff from the soil to water bodies may serve as an additional source of $\mathrm{Pb}$ contamination. Fertilizers often are contaminated by this element (Aro et al. 1998; McBride and Spiers 2001; Nziguheba and Smolders 2008; Bodnar et al. 2016).

In contrast to our expectations regarding high levels of $\mathrm{Hg}$ in piscivorous $\mathrm{CT}$ and partly piscivorous BHG, detectable concentrations of this element were found only in the eggshells of CT and ML (Table ES4). The lack of detectable concentrations of $\mathrm{Hg}$ in the eggshells of BHG may be explained by the frequent foraging of BHGs on anthropogenic food in winter that favor lower accumulations of $\mathrm{Hg}$ (Kitowski et al. 2015; Peterson et al. 2017) compared with foraging on fish favoring $\mathrm{Hg}$ accumulation in eggs, including eggshells (Monteiro and Furness 1995; Grajewska et al. 2015; Ackerman et al. 2016). Conversely, birds may have foraged in areas contaminated with $\mathrm{Hg}$, but this element may have been allocated to the egg content as has been reported previously for the black-tailed gull, Larus crassirostris (Agusa et al. 2005).

\section{Intersite Differences in Elemental Concentrations in Income Breeder, CT}

Significant intersite differences in the concentrations of 5 trace elements $(\mathrm{Cr}, \mathrm{Hg}, \mathrm{Ni}, \mathrm{Se}$, and $\mathrm{Sr})$ in CT eggshells (Table 4; ES5) suggest that this species, adopting an income breeder strategy, foraged close to breeding sites in distinct areas differing in habitat composition and elemental concentrations.

In contrast to the expected elevated concentrations of fertilizer-derived Cd (Lugon-Moulin et al. 2006; Nziguheba and Smolders 2008) in the eggshells of CTs breeding in sites with a high proportion of surrounding farmland (Pakość), no significant site effect was found. This may be explained by the generally low intensity of agrochemical use in small farms prevailing in the studied area (Statistical Office in Bydgoszcz 2011). Because high Cu levels may indicate high concentrations of aquatic prey, the lack of a significant site effect for $\mathrm{Cu}$ levels in eggshells may be explained by the lack of significant intersite differences in the area's water bodies (Table ES1). Significant intersite differences in the levels of five elements were found in the CT eggshells. The highest 
concentration of Se was found in CT eggshells at the Skoki Duże colony. However, the values found in the eggshells of all studied species were lower than those reported for other waterbirds (Table ES6, Table ES7), which was attributed to a very low Se content in the soils in Poland affecting its availability for organisms (Wasowicz et al. 2003; Nowakowska et al. 2014; Mirowski 2016). The highest levels of Se in eggshells from Skoki Duże may be explained by assimilation of this element from alternative sources, such as fish from watercourses affected by runoff from soils supplemented with Se-enriched fertilizers or by local oil/fuel spills in the vicinity of the Vistula River (Lemly 2004; Hartikainen 2005).

Significantly higher levels of $\mathrm{Ni}$ and $\mathrm{Sr}$ were found at Skoki Duże and Pakość compared with the Koronowo colony. In the case of the Skoki Duze colony, it may have been due to the foraging of CT in the Włocławek Reservoir (a water reservoir on the Vistula River) situated in close proximity $(<1 \mathrm{~km})$ to the colony. The Vistula River transports multiple pollutants, including $\mathrm{Ni}$ (25.2 tons annually) (Polish Central Statistical Office 2013). High Sr levels at Skoki Duże is likely attributable to the colony's location in a functioning gravel pit. Soil and parent rock are natural reservoirs of this element (Turekian and Kulp 1956; KabataPendias and Mukherjee 2007) and serve as major sources of contaminated fish and other aquatic organisms. High levels of $\mathrm{Ni}$ (and also $\mathrm{Cr}$ ) in the eggshells from Pakość may be attributable to emissions from a nearby factory producing machines for industry and mining often using alloys (Nriagu 1988; Studnicki et al. 2005; Duda-Chodak and Blaszczyk 2008). The highest $\mathrm{Cr}$ concentration was found in the colony at Pakość, which may be explained by the close proximity of a tannery. Wastewater from the tanning process is considered a major source of $\mathrm{Cr}$ pollution in wetland sediments as the untreated tannery effluent is characterized by high concentrations of $\mathrm{Cr}$, salts, chloride ions, sulfides, and sulfates (Pawlikowski et al. 2006; Rosales et al. 2017).

\section{Limitations of Our Study}

We are aware of some limitations of our study. First, our study is based on post-hatch eggshells. Eggshells and egg contents may have different trace-element levels (Morera et al. 1997; Agusa et al. 2005; Hashmi et al. 2013). It has been reported that $\mathrm{Cd}, \mathrm{Pb}$, and $\mathrm{Mn}$ concentrations in avian eggshells are higher than in egg contents (Kim and Oh 2014). Because an eggshell is mainly composed of $\mathrm{Ca}$, trace elements, such as $\mathrm{Cd}$ and $\mathrm{Pb}$, might interact with the metabolic pathway of Ca (Scheuhammer 1987). Consequently, they may be incorporated more easily in the eggshell (Dauwe et al. 1999). However, those differences may be advantageous in biomonitoring studies. Comparison of $\mathrm{Zn}$ and $\mathrm{Cu}$ concentrations in eggs of birds breeding in polluted and unpolluted areas revealed lack of differences for egg content and marked differences in eggshells. It indicates that the concentrations of both elements in the egg content are homeostatically controlled. In this context, the egg content is considered as less suitable as a bioindicator compared with the eggshell (Dauwe et al. 1999). Moreover, concentrations of some elements were reported to be similar $(\mathrm{Cu}, \mathrm{Mg}, \mathrm{Mg}$, and $\mathrm{Zn})$ or significantly correlated $(\mathrm{Cd}$, $\mathrm{Pb}, \mathrm{Cu}$ ) in eggshell and egg content (Kim and $\mathrm{Oh} 2014$ ). Anyway, caution should be use when interpreting results for particular elements. Second, our interpretations of the observed differences in elemental concentrations are mainly focused on dietary differences and local soil and water pollution sources. However, many other factors, such as metabolic state and health may affect the sequestration of particular elements into the egg.

Despite both mentioned limitations, analyses of contaminations levels in the post-hatched eggshells may serve as convenient, not invasive, tool for monitoring trace-element contaminations in birds (Dauwe et al. 1999; Lam et al. 2005; Ayas 2007; Ayas et al. 2008; Kim and Oh 2014).

\section{Conclusions}

Our study revealed significant inter-species differences in elemental concentrations in post-hatch eggshells of three sympatrically breeding waterbirds. Those differences were attributed to various diet compositions and geographic areas for gaining energy reserves for egg production. Comparisons with the eggshells of other waterbirds revealed that the studied birds generally did not accumulate high levels of toxic elements. Levels of Cr in ML and CT were exclusively elevated, which may be explained by their foraging on aquatic organisms in waterbodies polluted by this element. The results of our intersite comparisons reflecting local sources of contamination suggest that the eggshells of income breeders may be used as bioindicators of contamination levels in the vicinity of breeding sites. The decomposition of the eggshells of waterbirds serves as one of the local-scale mechanisms of pollution transfer from aquatic to terrestrial ecosystems.

Acknowledgements Eggshells were collected with permission from the Regional Department for Environmental Protection in Bydgoszcz (WPN.6401.1.4.2015.MO). The authors especially thank Jaroslaw Kowalski for assistance in the field.

Open Access This article is distributed under the terms of the Creative Commons Attribution 4.0 International License (http://creativecommons.org/licenses/by/4.0/), which permits unrestricted use, distribution, and reproduction in any medium, provided you give appropriate credit to the original author(s) and the source, provide a link to the Creative Commons license, and indicate if changes were made. 


\section{References}

Ackerman JT, Eagles-Smith CA, Herzog MP, Hartman CA (2016) Maternal transfer of contaminants in birds: mercury and selenium concentrations in parents and their eggs. Environ Pollut 210:145-154

Agusa T, Matsumoto T, Ikemoto T, Anan Y, Kubota R, Yasunaga G, Kunito T, Tanabe S, Ogi H, Shibata Y (2005) Body distribution of trace elements in Black-tailed gulls from Rishiri Island, Japan: age-dependent accumulation and transfer to feathers and eggs. Environ Toxicol Chem 24:2107-2120

Allen SE (1989) Analysis of vegetation and other organic materials. In: Allen SE (ed) Chemical analysis of ecological materials. Blackwell Scientific Publications, Oxford, pp 46-61

Anderson MJ (2001) A new method for non-parametric multivariate analysis of variance. Austral Ecol 26:32-46

Aro A, Alfthan G, Ekholm P, Varo P (1998) Effects of selenium supplementation of fertilizers on human nutrition and selenium status. Environmental chemistry of selenium. Marcel Dekker, New York, pp 81-97

Ayas Z (2007) Trace element residues in eggshells of grey heron (Ardea cinerea) and black-crowned night heron (Nycticorax nycticorax) from Nallihan Bird Paradise, Ankara-Turkey. Ecotoxicology 16:347-352

Ayas Z, Celikkan H, Aksu ML (2008) Lead (Pb) and copper (Cu) concentration in the eggshells of Audouin's gull (Larus audouinii) in Turkey. Turk J Zool 32:379-384

Becker PH, Ludwigs JD (2011) Common tern Sterna hirundo. In: Birds of western palearctic. Interactive 2.03. Oxford University Press

Bendell-Young LI, Bendell JF (1999) Grit ingestion as a source of metal exposure in the spruce grouse, Dendragapus canadensis. Environ Pollut 106:405-412

Bodnar M, Szczyglowska M, Konieczka P, Namiesnik J (2016) Methods of selenium supplementation: bioavailability and determination of selenium compounds. Crit Rev Food Sci 56:36-55

Bond AL, Diamond AW (2010) Nutrient allocation for egg production in six Atlantic seabirds. Can J Zool 88:1095-1102

Boos M, Zorn T, Le Maho Y, Groscolas R, Robin JP (2002) Sex differences in body composition of wintering Mallards (Anas platyrhynchos): possible implications for survival and reproductive performance. Bird Study 49:212-218

Brix H, Lyngby JE (1983) The distribution of some metallic elements in eelgrass (Zostera marina L.) and sediment in the Limfjord, Denmark. Estuar Coast Shelf Sci 16:455-467

Bukacinski D, Bukacinska M (2015) Common Tern Sterna hirundo (in Polish) (original title: Rybitwa rzeczna Sterna hirundo) STOP, Warszawa

Burger J, Gochfeld M (1996) Heavy metal and selenium levels in Franklin's gull (Larus pipixcan) parents and their eggs. Arch Environ Contam Toxicol 30:487-491

Butler MW, McGraw KJ (2013) Eggshell coloration reflects both yolk characteristics and dietary carotenoid history of female Mallards. Funct Ecol 27:1176-1185

Clarke KR (1993) Non-parametric multivariate analysis of changes in community structure. Aust J Ecol 18:117-143

Cramp S, Simmons KEL (1977) Mallard Anas platyrhynchos. In: Cramp S (ed) Birds of the western Palearctic. Handbook of birds of Europe, the Middle East and North Africa, vol 1. Oxford University Press, London, pp 505-519

Cuendet G (1983) Predation on earthworms by the Black-headed gull (Larus ridibndus L.). In: Satchell JE (ed) Earthworm ecology. Chapman and Hall, London, pp 415-424

Dauwe T, Bervoets L, Blust R, Pinxten R, Eens M (1999) Are eggshells and egg contents of great and blue tit suitable as indicators of heavy metal pollution? Belg J Zool 129:439-447
Demirezen D, Aksoy A (2006) Common hydrophytes as bioindicators of iron and manganese pollutions. Ecol Indic 6:388-393

Duda-Chodak A, Blaszczyk U (2008) The impact of nickel on human health. J Elem 13:685-693

Figuerola J, Mateo R, Green AJ, Mondain-Monval JY, Lefranc H, Mentaberre G (2005) Grit selection in waterfowl and how it determines exposure to ingested lead shot in Mediterranean wetlands. Environ Conserv 32:226-234

Fu J, Wang Q, Wang H, Yu H, Zhang X (2014) Monitoring of nondestructive sampling strategies to assess the exposure of avian species in Jiangsu Province, China to heavy metals. Environ Sci Pollut Res 21:2898-2906

Gionfriddo JP, Best LB (1999) Grit use by birds: a review. Curr Ornithol 15:89-148

Grajewska A, Falkowska L, Szumiło-Pilarska E, Hajdrych J, Szubska M, Frączek T, Meissner W, Bzoma S, Bełdowska M, Przystalski A, Brauze T (2015) Mercury in the eggs of aquatic birds from the Gulf of Gdansk and Wloclawek Dam (Poland). Environ Sci Pollut Res 22:9889-9898

Green AJ, Selva N (2000) The diet of post-breeding Marbled Teal Marmorenetta angustirrostris and Mallard Anas platyhrynchos in the Göksu delta, Turkey. Rev Ecol Terre Vie 55:161-169

Hammer $\varnothing$, Harper DAT, Ryan PD (2001) PAST: paleontological statistics software package for education and data analysis. Palaeontol Electron 4:9

Hartikainen H (2005) Biogeochemistry of selenium and its impact on food chain quality and human health. J Trace Elem Med Biol 18:309-318

Hashmi MZ, Malik RN, Shahbaz M (2013) Heavy metals in eggshells of cattle egret (Bubulcus ibis) and little egret (Egretta garzetta) from the Punjab province, Pakistan. Ecotoxicol Environ Saf 89:158-165

Horai S, Watanabe I, Takada H, Iwamizu Y, Hayashi T, Tanabe S, Kuno K (2007) Trace element accumulations in 13 avian species collected from the Kanto area, Japan. Sci Total Environ 373:512-525

iCAP (2010) iCAP 6000 Series ICP-OES spectrometer hardware manual. Cambridge, UK

Jurkiewicz-Karnkowska E (2005) Some aspects of nitrogen, carbon and calcium accumulation in molluscs from the Zegrzynski reservoir ecosystem. Pol J Environ Stud 14:173-177

Kabata-Pendias A, Mukherjee AB (2007) Trace elements from soil to human. Springer, New York

Khademi N, Riyahi-Bakhtiari A, Sobhanardakani S, Rezaie-Atagholipour M, Burger J (2015) Developing a bioindicator in the Northwestern Persian Gulf, Iran: trace elements in bird eggs and in coastal sediments. Arch Environ Contam Toxicol 68:274-282

Kim J, Oh JM (2014) Trace element concentrations in eggshells and egg contents of Black-tailed gull (Larus crassirostris) from Korea. Ecotoxicology 23:1147-1152

Kitowski I, Kowalski R, Komosa A, Sujak A (2015) Total mercury concentration in the kidneys of birds from Poland. Turk J Zool 39:693-701

Kitowski I, Indykiewicz P, Wiącek D, Jakubas D (2017) Intra-clutch and inter-colony variability in element concentrations in eggshells of the black-headed gull, Chroicocephalus ridibundus, in northern Poland. Environ Sci Pollut Res. https://doi.org/10.1007/ s11356-017-8635-z

Klaassen MA, Baarspul T, Deckers T, van Tienen P (2004) The relationship between carbon isotope ratios of hatchling down and egg yolk in Black-headed Gulls. J Field Ornithol 75:196-199

Komosa A, Kitowski I, Komosa Z (2012) Essential trace (Zn, Cu, Mn) and toxic $(\mathrm{Cd}, \mathrm{Pb}, \mathrm{Cr})$ elements in the liver of birds from Eastern Poland. Acta Vet (Beograd) 62:579-589 
Kottferova J, Korenekova B, Siklenka P, Jackova A, Hurna E, Saly J (2001) The effect of Cd and vitamin D3 on the solidity of the eggshell. Eur Food Res Technol 212:153-155

Lam JC, Tanabe S, Lam MH, Lam PK (2005) Risk to breeding success of waterbirds by contaminants in Hong Kong: evidence from trace elements in eggs. Environ Pollut 135:481-490

Łaszczyca P, Augustyniak M, Babczyńska A, Bednarska K, Kafel A, Migula P, Wilczek G, Witas I (2004) Profiles of enzymatic activity in earthworms from zinc, lead and cadmium polluted areas near Olkusz (Poland). Environ Int 30:901-910

Leach RM, Gross JR (1983) The effect of manganese deficiency upon the ultrastructure of the eggshell. Poultry Sci 62:499-504

Lemly AD (2004) Aquatic selenium pollution is a global environmental safety issue. Ecotoxicol Environ Saf 59:44-56

Lidwin-Kazmierkiewicz M, Pokorska K, Protasowicki M, Rajkowska M, Wechterowicz Z (2009) Content of selected essential and toxic metals in meat of freshwater fish from West Pomerania, Poland. Pol J Food Nutr Sci 59:219-224

Łuczyńska J, Tońska E, Łuczyński M (2009) Essential mineral components in the muscles of six freshwater fish from the Mazurian Great Lakes (northeastern Poland). Archiv Pol Fish 17:171-178

Lugon-Moulin N, Ryan L, Donini P, Rossi L (2006) Cadmium content of phosphate fertilizers used for tobacco production. Agron Sustain Dev 26:151

Luo J, Ye Y, Gao Z, Wang W (2016) Trace element enrichment in the eggshells of Grus japonensis and its association with eggshell thinning in Zhalong Wetland (Northeastern China). Biologia 71:220-227

Martinez-Haro M, Green AJ, Acevedo P, Mateo R (2011) Use of grit supplements by waterbirds: an experimental assessment of strategies to reduce lead poisoning. Eur J Wild Res 57:475-484

Mateo R (2009) Lead poisoning in wild birds in Europe and the regulations adopted by different countries. Ingestion of lead from spent ammunition: implications for wildlife and humans. In: Watson RT, Fuller M, Pokras M, Hunt WG (eds) Ingestion of lead from spent ammunition: implications for wildlife and humans. The Peregrine Fund, Boise, pp 71-98

McBride MB, Spiers G (2001) Trace element content of selected fertilizers and dairy manures as determined by ICP-MS. Commun Soil Sci Plan Anal 32:139-156

Migula P, Augustyniak M, Kowalczyk K (2000) Heavy metals, resting metabolism rates and breeding parameters in two populations of Black-headed Gull Larus ridibundus from the industrially polluted areas of Upper Silesia, Poland. Acta Ornithol $35: 159-172$

Mirowski A (2016) Selenium status in free-living animals in Poland. Życie Weterynaryjne (in Polish) 91:166-168

Monteiro LR, Furness RW (1995) Seabirds as monitors of mercury in the marine environment. Water Air Soil Pollut 80:851-870

Mora MA (2003) Heavy metals and metalloids in egg contents and eggshells of passerine birds from Arizona. Environ Pollut 125:393-400

Morera M, Sanpera C, Crespo S, Jover L, Ruiz X (1997) Inter- and intraclutch variability in heavy metals and selenium levels in Audouin's gull eggs from the Ebro Delta, Spain. Arch Environ Contam Toxicol 33:71-75

Morgan JE, Morgan AJ (1991) Differences in the accumulated metal concentrations in two epigeic earthworm species (Lumbricus rubellus and Dendrodrilus rubidus) living in contaminated soils. Bull Environ Contam Toxicol 47:296-301

Morgan JE, Morgan AJ (1999) The accumulation of metals $(\mathrm{Cd}, \mathrm{Cu}$, $\mathrm{Pb}, \mathrm{Zn}$ and $\mathrm{Ca}$ ) by two ecologically contrasting earthworm species (Lumbricus rubellus and Aporrectodea caliginosa): implications for ecotoxicological testing. Appl Soil Ecol 13:9-20

Nam DH, Anan Y, Ikemoto T, Okabe Y, Kim EY, Subramanian A, Saeki K, Tanabe S (2005) Specific accumulation of 20 trace elements in great cormorants (Phalacrocorax carbo) from Japan. Environ Pollut 134:503-514

Nicholson FA, Smith SR, Alloway BJ, Carlton-Smith C, Chambers BJ (2003) An inventory of heavy metals inputs to agricultural soils in England and Wales. Sci Total Environ 11:205-219

Nowakowska E, Pilarczyk B, Pilarczyk R, Tomza-Marciniak A, Bąkowska M (2014) Selenium Content in Selected Organs of Roe Deer (Capreolus capreolus) as a criterion to Evaluate environmental abundance of this element in Poland. Int $\mathrm{J}$ Environ Res 8:569-576

Nriagu JO (1988) Production and uses of chromium. In: Nriagu JO, Neiboer E (eds) Chromium in the natural and human environments. Wiley, New York, pp 81-104

Nziguheba G, Smolders E (2008) Inputs of trace elements in agricultural soils via phosphate fertilizers in European countries. Sci Total Environ 390:53-57

Obolewski KT, Skorbiłowicz E, Skorbiłowicz M, Osadowski Z (2010) Influence of chemical elements contained in reed Phragmites australis (Cav.) Trin. on epiphytic algae in riparian buffer zone. Fresen Environ Bull 19:348-353

Orłowski G, Kasprzykowski Z, Dobicki W, Pokorny P, Wuczyński A, Polechoński R, Mazgajski TD (2014) Trace-element interactions in rook Corvus frugilegus eggshells along an urbanisation gradient. Arch Environ Contam Toxicol 67:519-528

Orłowski G, Hałupka L, Pokorny P, Klimczuk E, Sztwiertnia H, Dobicki W (2016) The effect of embryonic development on metal and calcium content in eggs and eggshells in a small passerine. Ibis 158:144-154

Orłowski G, Hałupka L, Pokorny P, Klimczuk E, Sztwiertnia H, Dobicki W, Polechoński R (2017) The pattern of distribution and interaction of metals and calcium in eggshells and egg contents in relation to the embryonic development of eggs in a small passerine bird. J Ornithol 158:297-309

Packard MJ, Packard GC (1991) Patterns of mobilization of calcium, magnesium, and phosphorus by embryonic yellow-headed blackbirds (Xanthocephalus xanthocephalus). J Comp Physiol B 160:649-654

Pain DJ (1990) Lead shot ingestion by waterbirds in the Camargue, France: an investigation of levels and interspecific differences. Environ Pollut 66:273-285

Parzych A, Sobisz Z, Cymer M (2016) Preliminary research of heavy metals content in aquatic plants taken from surface water (Northern Poland). Desalin Water Treat 57:1451-1461

Pawlikowski M, Szalinska E, Wardas M, Dominik J (2006) Cr originating from tanneries in river sediments: a preliminary investigation from the Upper Dunajec River (Poland). Pol J Environ Stud $15: 885-894$

Peterson SH, Ackerman JT, Eagles-Smith CA (2017) Mercury contamination and stable isotopes reveal variability in foraging ecology of generalist California gulls. Ecol Indic 74:205-215

Polish Central Statistical Office (2013) Statistical yearbook of maritime economy. Szczecin

Radwan S, Kowalik W, Kornijow R (1990) Accumulation of heavy metals in a lake ecosystem. Sci Total Environ 96:121-129

Rosales RM, Faz A, Gomez-Garrido M, Munoz MA, Murcia FJ, Gonzalez V, Acosta JA (2017) Geochemical speciation of chromium related to sediments properties in the riverbed contaminated by tannery effluents. J Soils Sediments 17:1437-1448

Samecka-Cymerman A, Kempers AJ (2000) Bioindication of heavy metals with aquatic macrophytes: the case of a stream polluted with power plant sewages in Poland. J Toxicol Environ Health Part A 62:57-67

Sánchez-Virosta P, Espín S, García-Fernández AJ, Eeva T (2015) A review on exposure and effects of arsenic in passerine birds. Sci Total Environ 512:506-525 
Scheuhammer AM (1987) The chronic toxicity aluminum, cadmium, mercury and lead in birds: a review. Environ Pollut 46:263-295

Schierup HH, Larsen VJ (1981) Macrophyte cycling of zinc, copper, lead, and calcium in the littoral zone of a polluted and nonpolluted lake. I. Availability, uptake and translocation of heavy metals in Phragmites australis (Cav.) Trin. Aquat Bot 11:197-210

Schummer ML, Petrie SA, Badzinski SS, Deming M, Chen YW, Belzile N (2011) Elemental contaminants in livers of mute swans on Lakes Erie and St. Clair. Arch Environ Contam Toxicol 61:677-687

Sherfy MH, Kirkpatrick RL, Webb KE Jr (2001) Nutritional consequences of gastrolith ingestion in blue-winged teal: a test of the hard-seed-for-grit hypothesis. J Wildl Manag 65:406-414

Simonetti P, Botté SE, Marcovecchio JE (2015) Exceptionally high Cd levels and other trace elements in eggshells of American oystercatcher (Haematopus palliatus) from the Bahía Blanca Estuary, Argentina. Mar Pollut Bull 100:495-500

Skoric S, Visnjić-Jeftic Z, Jaric I, Djikanovic V, Mickovic B, Nikcevic $M$, Lenhardt $M$ (2012) Accumulation of 20 elements in great cormorant (Phalacrocorax carbo) and its main prey, common carp (Cyprinus carpio) and Prussian carp (Carassius gibelio). Ecotoxicol Environ Saf 80:244-251

Soons MB, Brochet AL, Kleyheeg E, Green AJ (2016) Seed dispersal by dabbling ducks: an overlooked dispersal pathway for a broad spectrum of plant species. J Ecol 104:443-455

Statistical Office in Bydgoszcz (2011) Statistical Yearbook of Kujawsko -Pomorskie Voivodship 2011. Statistical Office in Bydgoszcz, Bydgoszcz
StatSoft Inc (2014) Statistica (data analysis software system), version 12. www.statsoft.com

Stephens PA, Boyd IL, McNamara JM, Houston AI (2009) Capital breeding and income breeding: their meaning, measurement, and worth. Ecology 90:2057-2067

Studnicki A, Kilarski J, Przybył M, Suchoń J (2005) Technological experiments of production castings of chromium cast iron in the foundry. Arch Foundry 5:293-302

Swiatkiewicz S, Koreleski J (2008) The effect of zinc and manganese source in the diet for laying hens on eggshell and bones quality. Vet Med 53:555-563

Szymczyk K, Zalewski K (2003) Copper, zinc, lead and cadmium content in liver and muscles of mallards (Anas platyrhychnos) and other hunting fowl species in Warmia and Mazury in 1999-2000. Pol J Environ Stud 12:381-386

Turekian KK, Kulp JL (1956) The geochemistry of strontium. Geochim Cosmochim Acta 10:245-296

Vernon JDR (1972) Feeding habitats and food of the black-headed and common gulls. Bird Study 19:173-186

Wasowicz W, Grimadzinska J, Rydzynska K, Tomczak J (2003) Selenium status of low-selenium area residents: Polish experience. Toxicol Lett 137:95-101

Wheeler AP (1992) Mechanisms of molluscan shell formation. In: Bonucci E (ed) Calcification in biological systems. CRC Press, Boca Raton, pp 179-215 